\title{
Theological Libraries Serving Immigrant Communities
}

\author{
Susan Ebertz, Wartburg Seminary
}

\begin{abstract}
As theological institutions begin to reach out more to immigrant communities through programs and degrees aimed at these groups, libraries will need to understand how best to serve the research and academic needs of these students. This may mean non-English resources, culturally relevant resources, and staffing changes. The presenter provided basic information and group divided into four smaller discussion groups.
\end{abstract}

\section{OVERVIEW OF THEOLOGICAL LIBRARIES AND IMMIGRANT COMMUNITIES}

Understanding context always helps in understanding the perspective of the person speaking. My context is the Midwest United States in a small town of 60,000 people. I am at a Lutheran seminary. I use the term "immigrant communities" even though I realize that this may not be the best way to identify the group. I am doing this session because I want to learn how I can better serve these communities.

It is important to understand your own context and the types of information available to you. Your state may have information. Iowa has the Iowa State Data Center. I learned more about immigration through this site. For example, in May 2020, the Center published a document on their website about "Asian/Pacific Americans In Iowa: 2020” (www.iowadatacenter.org/Publications/api2020.pdf). I learned through the document about the percentage of the "foreign born” population that was from Asia and when they arrived. I also learned that my city had the largest number of Native Hawaiians and/or other Pacific Islanders in Iowa.

The United States Census Bureau has census information about your state. Click on your state on this map (data.census.gov/cedsci/ map?q=american\%20community\%20survey\&tid=ASMAREA2017. AM1831BASIC01\&mode $=$ selection\&vintage $=2018$ ) to find out more information, including languages spoken at home. 
Another useful map is one that shows migration in the United States in 1900, 1950, and 2012. This map (www.nytimes. com/2014/08/16/upshot/mapping-migration-in-the-united-statessince-1900.html) not only shows the migration patterns but also the percentages for "born outside the US" in each state.

I have noticed that theological institutions are reaching out more to immigrant communities within the United States. Some of this seems to be for the ethical reason of diversifying the church so that it reflects the diversity within the population. The other reason seems to be financial. Immigrant communities are a new market.

Our seminary's strategic plan includes reaching out to immigrant groups. In order to prepare for this new area, I need to increase the Spanish-language holdings. Last fall, I asked a student whose first language is Spanish how I can help him. He said that it would be helpful for him if he have more resources in Spanish, and particularly journals. I don't know Spanish, so it is difficult for me to acquire the best resources. I also discovered that there is not a lot of Spanish-language resources. I decided that more content needed to be created. I suggested to our faculty that it would be helpful for them to tell our denominational publisher to publish more in Spanish. It would also be helpful to recommend that particularly important texts be translated into Spanish. I also spoke to our denominational publisher. Lobbying our publishers is one way to increase the number of resources. I also talked with one of the editors of our seminary journal, which is published with the Lutheran School of Theology in Chicago. I suggested that the journal be translated into Spanish. I was told that the cost would be too high. I then suggested that at least one article in each issue be in Spanish. I am curious where this will go. Our advocacy will help increase Spanish-language materials.

\section{CONVERSATION QUESTIONS}

We then broke up into 4 groups. We discussed the following:

- What is your context?

- What is your experience or inexperience?

- What resources have you found helpful in serving students?

The groups reported back the following:

- The language most spoken is Spanish. 
- Some students do not find anything in their language.

- There's no formal orientation to the library; they focus on the English-learning, MA/MDiv students that are coming from Spanish-speaking population to serve various Archdioceses (esp. in Milwaukee) and African students, for whom English is their 4th or 5 th language.

- Special separate orientation for international student cohort each year. Special Collections visitors are coming from all over the world. We have a vast collection of non-English titles within Burke and within the wider Columbia University library setting.

- We have a reading center that is dedicated to helping their immigrant students acclimate to life and studying in the United States. Attendance at the reading center is required of these students during their summer sessions.

- We have an ESL coordinator who provides individual assistance and gathers materials for them.

- We are in the process of hiring a Spanish-speaking librarian.

- We have digitized items from collaborative programs in Latin America.

- Abingdon recently published several works in Spanish.

- Digitalia is one of the vendors [at the conference]-you should talk to them. They have some religion \& theology titles-we've subscribed to their product for several years because it's all Spanish-language \& they're the ones who have the Verbo Divino commentaries.

- Also, there have been quite a few recent Spanish-language additions in religion \& theology in GOBI, but you have to look for them!

I feel we need a longer period for this topic at next year's conference. 